\title{
Reuters: Principles Of Trust Or Propaganda?
}

Henry I. Silverman, Roosevelt University, USA

\begin{abstract}
This paper examines a sample of fifty news-oriented articles related to the Middle East conflict published on the Reuters proprietary websites across a three month study window. A combination of Ethnographic Content Analysis and primary survey data are employed to identify, code and validate reporting/ethical failures in the articles, i.e., propaganda, logical fallacies, and violations of the Reuters Handbook. Tests are run to measure for 1) shifts in audience attitudes and support for the primary belligerent parties in the Middle East conflict following readings of the sample and, 2) associations between the reporting/ethical failures and audience attitudes/support. Over 1,100 occurrences of reporting/ethical failures across forty-one subcategories are identified and a significant shift in audience attitudes and support following article readings is observed. Significant associations are found between 1) the use of atrocity propaganda and audience favorability/sympathy toward the Arabs/Palestinians; 2) the use of the appeal to pity fallacy and audience favorability/sympathy toward the Arabs/Palestinians; and 3) the use of atrocity propaganda, appeal to pity and appeal to poverty fallacies, and audience motivation to take supportive action on behalf of the Arabs/Palestinians. It is inferred from the evidence that Reuters engages in systematically biased storytelling in favor of the Arabs/Palestinians and is able to influence audience affective behavior and motivate direct action along the same trajectory. This reflects a fundamental failure to uphold the Reuters corporate governance charter and ethical guiding principles.
\end{abstract}

Keywords: Reuters; Journalism; Propaganda; Bias; Ethics; Corporate Governance; Israel; Palestinian Arabs; Ethnographic Content Analysis

\section{INTRODUCTION}

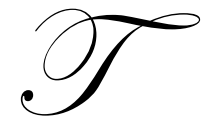

homson Reuters ("Reuters") was formed in 2008 when the Thomson Corporation and Reuters Group PLC combined to create the world's largest international multimedia news agency, providing “... world news, business news, technology news, headline news... on Reuters.com, video, mobile, and interactive television platforms". ${ }^{1}$

Reuters employs over 2,700 journalists in 200 bureaus $^{2}$ globally including approximately 70 journalists in Israel and the Palestinian territories. ${ }^{3}$ Elsewhere in the Middle East, there are Reuters news bureaus in Egypt, Jordan, Lebanon, Kuwait, the United Arab Emirates, Saudi Arabia, Iraq, Iran and Turkey. ${ }^{4}$

As a news agency (wire service), Reuters sells its content to hundreds of other media companies around the world including newspapers, magazines, radio, and television broadcasters. Reuters text newswires provide coverage of regional, national and international events in 20 languages, covering all areas of news and humaninterest stories. $^{5}$ In July 2011, the Reuters.com website drew an average of more than 46 million visitors per

\footnotetext{
${ }^{1}$ http://www.reuters.com/. Retrieved September 1, 2010.

2 Thomson Reuters Fact Book 2010. http://ir.thomsonreuters.com/phoenix.zhtml?c=76540\&p=irol-factbook. Retrieved April 10, 2011.

${ }^{3} \mathrm{http}: / /$ blogs.reuters.com/axismundi/2009/02/06/welcome-to-jerusalem-centre-of-the-world/. Retrieved September 1, 2010.

${ }^{4}$ http://thomsonreuters.com/about/locations. Retrieved September 1, 2010.

5 Thomson Reuters Fact Book 2010. http://ir.thomsonreuters.com/phoenix.zhtml?c=76540\&p=irol-factbook. Retrieved April 10, 2011.
} 
month. $^{6}$

Reuters maintains a corporate governance charter known as the Trust Principles, discussed in detail in its annual report and on its website:

Thomson Reuters is dedicated to upholding the Trust Principles and to preserving its independence, integrity and freedom from bias in the gathering and dissemination of information and news [...]

The Trust Principles are:

1. That Thomson Reuters shall at no time pass into the hands of any one interest, group or faction;

2. That the integrity, independence and freedom from bias of Thomson Reuters shall at all times be fully preserved;

3. That Thomson Reuters shall supply unbiased and reliable news services to newspapers, news agencies, broadcasters and other media subscribers and to businesses governments, institutions, individuals and others with whom Thomson Reuters has or may have contracts;

4. That Thomson Reuters shall pay due regard to the many interests which it serves in addition to those of the media; and

5. That no effort shall be spared to expand, develop and adapt the news and other services and products so as to maintain its leading position in the international news and information business. ${ }^{7}$

Journalists working for Reuters are also subject to an extensive editorial handbook, the Handbook of Journalism (HoJ), which sets out guiding ethical principles and requires all professional activities to be "independent, free from bias and executed with the utmost integrity". Under the lead section, Standards and Values, the HoJ lists 10 "absolutes of Reuters journalism" including the stipulation that reporters, "always strive for balance and freedom from bias" in their work. ${ }^{8}$

In recent years, there have been documented claims by various media watchdogs suggesting that Reuters' reporting of the Arab-Israeli conflict is systematically biased, regularly violates the Reuters Trust Principles as well as guidelines set out in the Reuters HoJ, and employs propaganda techniques to promote an Arab narrative and political interests in the conflict. ${ }^{9}$ On July 26, 2003 for example, the internet website Little Green Footballs noted a Reuters story which suggested, falsely, that Israel had failed to honor its treaty commitments to the Palestinian Arabs. ${ }^{10}$

There have also been reports of Reuters publishing doctored photographs on its website and supplying these to other media firms. During the war between Israel and the Lebanese militia group Hezbollah in 2006 for example, Reuters was compelled to withdraw a photo of smoke rising from buildings in Beirut, purportedly caused by Israeli bombing, after a number of photographers and bloggers (web loggers) noted that the images appeared to have been artificially altered to include additional smoke and damage. Reuters subsequently acknowledged that "photo editing software was improperly used" and terminated its ties with the contributing photographer. ${ }^{11}$

While Reuters has occasionally acknowledged factual errors of an unsystematic nature in its stories, the media firm has never publicly admitted to a policy of bias or advocacy on behalf of any of its story subjects. Indeed, such conscious bias or willful advocacy would be a clear contravention of the Reuters code of ethics and governing charter, the Trust Principles.

\footnotetext{
${ }^{6}$ http://www.trafficestimate.com/reuters.com. Retrieved August 3, 2011.

7 http://thomsonreuters.com/about/trust principles/. Retrieved September 1, 2010.

${ }_{8}^{8} \mathrm{http}: / /$ handbook.reuters.com/index.php/Standards_and_Values. Retrieved October 18, 2010.

9 www.r-mew.blogspot.com. Retrieved September 13, 2010.

${ }^{10} \mathrm{http}: / /$ littlegreenfootballs.com/article/7618 More Reuters Arab Propaganda. Retrieved September 13, 2010.

11 http://www.msnbc.msn.com/id/13165165/. Retrieved September 13, 2010.
} 


\section{LITERATURE}

At its essence, propaganda may be defined as the control of attitudes via the manipulation of symbols (Lasswell and Blumenstock, 1939). According to Smith (1989), propaganda is any conscious attempt "to influence the beliefs of an individual or group, guided by a predetermined end and characterized by the systematic use of irrational and often unethical techniques of persuasion". Synonyms for propaganda frequently include: lies, distortions, deceit, manipulation, mind control, psychological warfare, brainwashing, and spin (Jowett and O’Donnell, 1999). Ellul (1965) argues that nearly all biased messages in society are propagandistic.

Sproule (1994) draws both a link and a distinction between propaganda and persuasion by defining the former as "organized mass persuasion with covert intent". To constitute propaganda, Jowett and O'Donnell (1999) suggest that communication meet several criteria including an effort to influence the behavior of the audience; propaganda is thus defined as, "the deliberate, systematic attempt to shape perceptions, manipulate cognitions, and direct behavior to achieve a response that furthers the desired intent of the propagandist". These authors construct a purpose model of propaganda, which identifies key components in propaganda as controlling the flow of information, managing public opinion, and influencing behavior patterns. Smith (1989) however, does not argue that a specific influence effect must be proved for an analyst to conclude the presence of propaganda as there is always the possibility of different effects on different audiences.

Propaganda consists of a variety of approaches, techniques, and types. Fundamentally, the propagandist attempts to build a case for a particular conclusion by arraying only those materials which lend support to that conclusion (Smith, 1989). This is deliberate and associated with a clear institutional ideology and objective (Jowett and O'Donnell, 1999). Pratkanis and Turner (1996) characterize the propaganda effort as an attempt to "move a recipient to a predetermined point of view by using simple images and slogans that truncate thought by playing on prejudices and emotions". Techniques are also more sophisticated and include withholding vital information, using meaningless association, invoking heuristic devices, and other strategies of questionable ethics (Pratkanis and Aronson, 1991). Jowett and O'Donnell (1999) add to this list, fabricating and distorting information and the release of information at predetermined times, i.e., in sequence or juxtaposed with other information as a way of distorting the facts and influencing public perception.

In 1937, the Institute for Propaganda Analysis (IPA), a group of US academics, journalists and business leaders formed to study propaganda and its effects on the public and identified common rhetorical devices in use at the time (Lee and Lee, 1972). These included techniques like card stacking, i.e., slanting a message by omitting key facts or statistics; name calling, i.e., attaching a negative label to a person or thing; and bandwagon, i.e., creating the impression of widespread support for a group or movement so as to compel others to adopt the same cause or viewpoint.

Brown's "inventory" (1963), which incorporates several logical fallacies, became part of the propaganda lexicon in the mid-1960s. Amongst other devices identified here are stereotyping, selection, repetition, overt lies, assertion, and appeal to authority.

Smith (1989) establishes four primary categories of propaganda techniques: falsehoods, omissions, distortions (including logical fallacies), and suggestions. Within these constructs are devices like symbolic fiction, i.e., a false claim endorsed by some reputedly respectable and disinterested party; allusion, i.e., an assertion advanced without proof; multiple standards, i.e., the asymmetric judging of values or achievements between two individuals or groups; historical reconstruction, i.e., the systematic elimination or fabrication of elements of the historical record; and asymmetrical definition, i.e., the use of words which have a substantially different meaning for the audience than for the propagandist.

Jowett and O'Donnell (1999) note that propaganda relies on exaggeration and innuendo and uses language that tends to deify a cause and demonize opponents. These authors cite Chomsky's (1992) references to the metaphorical language employed by Western governments to rationalize and encourage intervention against the Soviet Union during the Cold War era, e.g., "the rot may spread"; "the virus may infect others". 
Types of propaganda include white, gray, and black. Whereas white propaganda comes from a source that is correctly identified such that the information tends to be accurate (although one-sided), black propaganda is credited to a false source and engages in deceptions, fabrications, and overt lies. Gray propaganda lies somewhere in between the two (Jowett and O'Donnell 1999). Disinformation and the Big Lie, e.g., Hitler's mendacious attacks on world Jewry, are illustrations of black propaganda. There is also integration propaganda which seeks conformity and stable behavior amongst its audience (Ellul, 1965) and agitation propaganda (agitprop) which alternatively attempts to arouse people to participate in or support a cause often at odds with the status quo (Jowett and O’Donnell 1999).

For well over a century, philosophers, psychologists, and communications researchers have speculated on the dynamics associated with successfully manipulating audience attitudes. Qualter (1962) cites the English philosopher Graham Wallas (1908) with the latter's argument that people are governed to a large extent by "affection and instinct" rather than by reason and are therefore subject to the inducement of feelings, beliefs, and acts via the power of suggestion. Similarly, drawing on Freudian psychoanalytic theory, Lasswell \& Blumsenstock (1939), argue that rather than respond rationally to rigorous analytical arguments, people tend to react on a subconscious level to symbols which evoke emotional impulses (see appeal to pity). Laswell (1927) believed that human responses to many forms of propaganda were immediate and uniform, although this theory was not based on empirical research. Alternatively, in their study of the persuasion process and attitude change, Zimbardo and Leippe (1991) take a learning theory approach which suggests that the more one is exposed to an idea, the more one is likely to accept it as true. (See repetition). Bryant (1953) argues that the power of propaganda lies in its exclusion of competing ideas, its ability to short circuit informed judgments and subvert rational processes.

Propaganda has figured prominently during times of war as a means to discredit and demonize an adversary; indeed, the term psychological warfare is often defined as the use of propaganda against an enemy (Linebarger, 1954). During the first world war, both the allied powers and Germany circulated false atrocity stories of massacres and mistreatment of civilians by torture and starvation so as to raise public funds and encourage enlistment to halt "inhuman acts" (Jowett and O'Donnell 1999). The Bryce Commission report, headed by an eminent British legal expert and translated into 30 languages, found a "compelling mass of evidence" to substantiate German atrocities (Read, 1941) - even though the veracity of depositions taken from Belgian witnesses is still in doubt today. This report had a powerful influence on public perceptions of the "barbarity" of German actions and may have been instrumental in US President Woodrow Wilson's decision to declare war against Germany (Jowett and O'Donnell 1999). Adolph Hitler praised the British propaganda machine in his book Mein Kampf and in large measure, based his own propaganda techniques on British methods (Hitler, 1925, 1926/2009).

Over successive decades, the press and mass media have played an increasingly leading role in efforts to shape audience opinion via the control of information and dissemination of propaganda. Control of information is accomplished in large part via the process of gatekeeping, where certain items are selected to appear in media publications while others are "killed" by editors (Rogers, 1994). Shaw and McCombs (1974) argue that a media gatekeeper has the power to set the agenda for an audience by selecting, prioritizing, screening, interpreting, emphasizing, and distorting information. In a survey of undecided voters during the 1968 American presidential election, these researchers found significant correlation between issues highlighted in the news media and those issues regarded as key by voters - despite widely divergent concerns voiced by the candidates (McCombs and Shaw, 1972). The gatekeeper is particularly influential when it is a monopoly or quasi-monopoly and the message is consistent and repetitious. Under such circumstances, the audience is unlikely to challenge the message (Jowett and O’Donnell, 1999). Weschler (1983) for example, notes that government-run media in Poland saturated the public airwaves and newspapers with negative material about the Solidarity movement prior to its rise to power successfully instilling a widespread antipathy for Solidarity leaders.

Notable illustrations of media orchestration and dissemination of propaganda can be seen in reporting during the 1990 Gulf War and later, in the military conflagration in the Balkans. In the former case, those opposing war with Iraq sought to associate the conflict with the failed US military effort in Vietnam so as to encourage uncertainty and anti-war sentiment across the American public. In an analysis by the Freedom Forum of approximately 66,000 news stories in major newspapers, news services, and evening television news during the Gulf War, researchers found 7,299 occurrences of the word "Vietnam", three times more than any other descriptive word 
or term, with the phrase "another Vietnam" representing nearly two-thirds of the total (Lamay, 1991). In the case of the Balkans, Brock (1993-94) argues that the conflict produced an "unprecedented and unrelenting onslaught [of propaganda] combining modern media techniques and advocacy journalism". Hume notes for example, the initial broadcast by ITN News in Britain, subsequent broadcast by ABC News in the US and publication in newspapers worldwide, of pictures of gaunt Bosnian Muslims near or behind barbed wire at a transit camp presented as prima facie evidence that the Serbs were organizing a Nazi-style Holocaust (Hammond and Herman, 2000). This catalog of tendentious images and other atrocity propaganda had a powerful emotional impact on audiences and may have served to mobilize public support for the subsequent NATO bombing of Serbia.

\section{METHODOLOGY}

To test for the presence of and analyze propaganda, Jowett and O'Donnell (1999) set out a list of "divisions" which include identifying the ideology and purpose of the propaganda campaign, special techniques employed to maximize effect, as well as effects (on the audience) and evaluation thereof. These authors recommend looking for a set of beliefs, values, attitudes, behaviors, as well as ways of thinking and perceiving that are agreed and have become a norm for the society or organization behind the propaganda. As the intent of the propagandist is often covert however (Sproule, 1994), one may not expect the organization managing the propaganda campaign to openly disclose or to facilitate the discovery of its ideology and purpose. This is particularly the case where the press is involved and the subject news organization is pledged to a policy of unbiased reporting. Further, Smith (1989) argues that demonstrating the conscious use of propaganda techniques creates an unreasonable burden of proof for the analyst -- although in the case of knowledgeable professionals, e.g. journalists, propaganda in the form of systematic assertions contrary to fact or selective reporting provides strong evidence of conscious deceit.

While it may not always be possible to identify an explicit ideology or purpose associated with the propaganda campaign via direct examination of the society or organization orchestrating the campaign, qualitative and quantitative content analysis, particularly ethnographic content analysis, of documents produced as part of the campaign may be employed to infer ideology and purpose as well as to examine for and reveal the approach, types of propaganda, e.g., white, black, and special techniques discussed earlier, e.g., repetition, omissions, etc. enlisted by the propagandist.

Content analysis is "the investigation of communications messages by categorizing message content into classifications in order to measure certain variables" (Rogers, 1994). As a research methodology, content analysis is rooted in the subject-classification of library books and cryptology and has been in widespread use in media and sociological studies for decades. Rogers (1994) credits Harold Lasswell as the developer of content analysis citing his seminal study of propaganda in World War I. In a study of American "morale programs" broadcast on radio during World War II, Merton (1968) reports on the use of content analysis to identify symbols associated with the Allied and Axis countries, respectively, and finds these symbols positively correlated suggesting that the producers of the programs view the Allies almost exclusively within the context of their military role in helping to defeat the enemy. The same study finds much more extensive use of personification stereotyping in references to the Axis than to the Allies which the researchers conclude reflects a deliberate effort to portray the enemy as a small group of evil individuals.

Silverman (1993) notes that ethnography seeks to understand the organization of social action in particular settings and Hammersley and Atkinson (1983) argue that as written accounts are an important feature of many settings, ethnographers need to take account of documents as a reflection of the setting under investigation. These latter authors cite the extensive use of documents by Gamst (1980) in his study of locomotive engineers, and in research emanating from the early Chicago School. Patton (1990) observes that a particularly rich source of information about many programs is program records and documents and that “... in contemporary society, all programs leave a trail of paper that the evaluator can follow and use to increase knowledge and understanding about the program". Hammersley and Atkinson (1983) again:

The presence and significance of documentary products provides the ethnographer with a rich vein of analytic topics, as well as a valuable source of information. Such topics include: How are documents written? How are they read? Who writes them? Who reads them? For what purpose? On what occasions? With what outcomes? What is recorded? What is omitted? What is taken for granted? What does the writer seem to take for granted about the 
reader(s). What do readers need to know in order to make sense of them?

Altheide (1987) suggests that several aspects of an ethnographic research approach can be applied to document analysis to produce Ethnographic Content Analysis (ECA), defined generally as the reflexive analysis of documents (Plummer, 1983). Although Altheide (1987) acknowledges that ECA has been less widely recognized as a distinctive research method, he notes that various facets of the approach are apparent in document analyses by historians, literary scholars, and social scientists. More recently, Altheide (1996) defines ECA as "an integrated method, procedure, and technique for locating, identifying, retrieving, and analyzing documents for their relevance, significance, and meaning", where "the emphasis is on discovery and description, including search for contexts, underlying meanings, patterns, and processes...". Thematic categories using ECA are established both $a$ priori and through a content analysis of text. Once the researcher has derived categories and a coding system from the ethnographic study data, quantitative content analysis design provides a set of procedures to systematically code the categories with reliability checks to analyze, validate, and report the results (Altheide, 1987; Smith, Sells, and Clevenger, 1994). Within ECA, concept development, sampling, data collection, data coding, data analysis, and interpretation are reflexive (Plummer, 1983; Altheide, 1987).

Articles prepared by staff writers and reviewed by editors in a news organization prior to publication are a product, ultimately, of the organization itself. As such, these articles are essentially cultural artifacts (Hodder, 2000) or "patterns of cultural construction" (Chambers, 2000) unique to a specific group of industry professionals, i.e., journalists. Notwithstanding the fact that stories produced by a news agency are generally written for an audience with a diverse set of opinions and are advertised to meet certain standards for objectivity or neutrality, these documents may in fact, violate these standards, reflect systematic bias, and/or incorporate propaganda techniques idiosyncratic to the agency or to the mass media generally. For the lay reader, these violations, biases and techniques will often be opaque or undetectable. Merton (1968) notes that "mere impressionism" of propaganda is not enough; adequate appraisal can only be achieved via systematic procedures. Stories produced by the agency are thus subject to rigorous discovery and interpretive research procedures supporting an ECA approach to analysis.

As indicated above, Jowett and O'Donnell (1999) also propose testing for the effects of propaganda on the audience. The focus here is on how successfully audience behavior is directed toward meeting the purpose of the campaign. Other researchers however, argue that it is not necessary to demonstrate specific behavioral effects in order to prove the presence of propaganda as effects may vary from one audience (sample) to another (Smith, 1989). One approach to reconciling these views is to bifurcate audience behavior into overt behavior, i.e., behavior that can be observed, and what Triandis (1977) refers to as affective behavior, that is, emotional reactions to people and events such as feelings of attraction or disgust, and to test for the latter even when the former (overt behavior) is unobservable or unchanged. This would be similar in some respects to early empirical research in persuasion that sought to measure audience attitudes or changes in attitude in response to propaganda. Utilizing attitude-measuring surveys for example, Rosenthal (1934) found that Russian silent propaganda films modified the socioeconomic attitudes of students in the US. Such surveys were based on those employed by Likert (1932) who developed a fivepoint linear scale measuring attitude strength ranging from "strongly approve" to "strongly disapprove".

For Patton (1999), research credibility depends critically on “... rigorous techniques and methods for gathering high-quality data that are carefully analyzed, with attention to issues of validity, reliability, and triangulation" [italics, this writer]. Triangulation, a concept originally introduced by Webb, Campbell, Schwartz, and Sechrest (1966) and then applied to qualitative inquiry by Denzin (1978) captures the notion of the importance of examining phenomenon from a variety of vantage points so as to establish the trustworthiness (validity) of qualitative inquiry (Banning, date unknown). Denzin (1978) defines four basic types of triangulation: 1) methodological triangulation, 2) data triangulation, 3) investigator triangulation, and 4) theory triangulation. A multi-methods approach to inquiry - a mixture of qualitative and quantitative analysis - is the embodiment of methodological triangulation. According to Denzin (1978), "between-method triangulation can take many forms, but its basic feature will be the combination of two or more different research strategies in the study of the same empirical units". The rationale for this strategy is that "... the flaws of one method are often the strengths of another; and by combining methods, observers can achieve the best of each while overcoming their unique deficiencies" (Denzin, 1978). In his study of investment company disclosure documents, Silverman (2006) triangulates with qualitative and quantitative methodologies to reveal encoded risk-return profiles. 


\subsection{Questions for study}

The study seeks to answer the following questions:

1. With respect to articles on the Middle East conflict published by Reuters on its news website, can failures to report events accurately, neutrally, or in compliance with ethical and corporate standards, e.g., the use of propaganda; logical fallacies, and/or violations of the Reuters Handbook of Journalism, be detected?

2. If present, what propaganda devices, logical fallacies, and/or violations occur?

3. How prevalent are occurrences of the reporting/ethical failures identified in nos. 1 and 2 above?

4. Do Reuters articles on the Middle East conflict influence a sample of readers to feel more sympathetic/favorable towards one or the other belligerent parties?

5. Do Reuters articles on the Middle East conflict influence a sample of readers to feel more motivated to take supportive action on behalf of one or the other belligerent parties?

6. What are the associations between specific reporting/ethical failures and the tendency for readers to feel sympathetic or favorable towards one or the other belligerent parties?

7. What are the associations between specific reporting/ethical failures and the tendency for readers to feel motivated to take supportive action on behalf of one or the other belligerent parties?

8. What can be inferred about the ideology or purpose of Reuters Middle East reporting from the data?

Qualitative analysis of the data, i.e., Ethnographic Content Analysis, will be employed to address questions (1), (2), and (8). Quantitative analysis, i.e., frequency counts, descriptive statistics, linear-scale surveys, meanvariance and regression analysis, will be employed to address questions (3) - (7). Employed together, qualitative analysis and quantitative analysis will meet Denzin's requirement for suitable methodological triangulation discussed above and contribute to the validity of the inquiry and results as suggested by Banning, also above.

\subsection{Data sources}

The primary data set consists of fifty news, "analysis" "feature" and "factbox" stories published on the Reuters proprietary websites between May 31, 2010 and August 31, 2010 and focusing on the Middle East conflict between Israel, on the one hand, and the Palestinian Arabs/Arab states on the other. The data set has been drawn employing random sampling (Krippendorf, 2004).

\subsection{Procedures}

The stories were examined using ECA as discussed above. The literature review and questions for study facilitated the identification of some general conceptual categories and descriptive themes in the materials, which were noted. Categories provide structure for grouping units of analysis into the same conceptual units that have similar meaning (USGAO, 1989), however as Altheide (1987) points out, "although [certain] categories and variables initially guide the [ECA] study, others are allowed and expected to emerge throughout the study". Thus, ECA is a process of constant discovery and constant comparison of meanings and nuances (Glaser and Strauss, 1967). It is important however, to ensure that caution is employed in relation to how one defines categories and assigns patterns of language use into each category to avoid a claim of "forcing" an outcome. In this study, this type of control is aided by, 1) the classification of propaganda approaches and techniques identified by researchers in previous studies, and 2) the public availability of, and detailed entries for, ethical guidelines found in the Reuters Handbook of Journalism.

Employing a reflexive process, I have worked across documents in the sample and have employed a process of iteration between the data and the emerging classification system. As Altheide (1987) suggests, once the categories and coding system have been derived using ECA, a quantitative content analysis design can provide a set of procedures to code the categories systematically with reliability checks embodied in the framework to analyze, validate and report results. As indicated earlier, ethnographic content analysis is used to document and understand the communication of meaning, as well as to verify theoretical relationships (Altheide, 1987). Informed by this approach, the individual data elements in each category were examined within the context of the Reuters Handbook of Journalism and various propaganda models discussed in the literature review, interpreted, and subsequently 
subsumed into broader, generalized categories for further analysis. The final categories and definitions can be viewed in Figure 1.

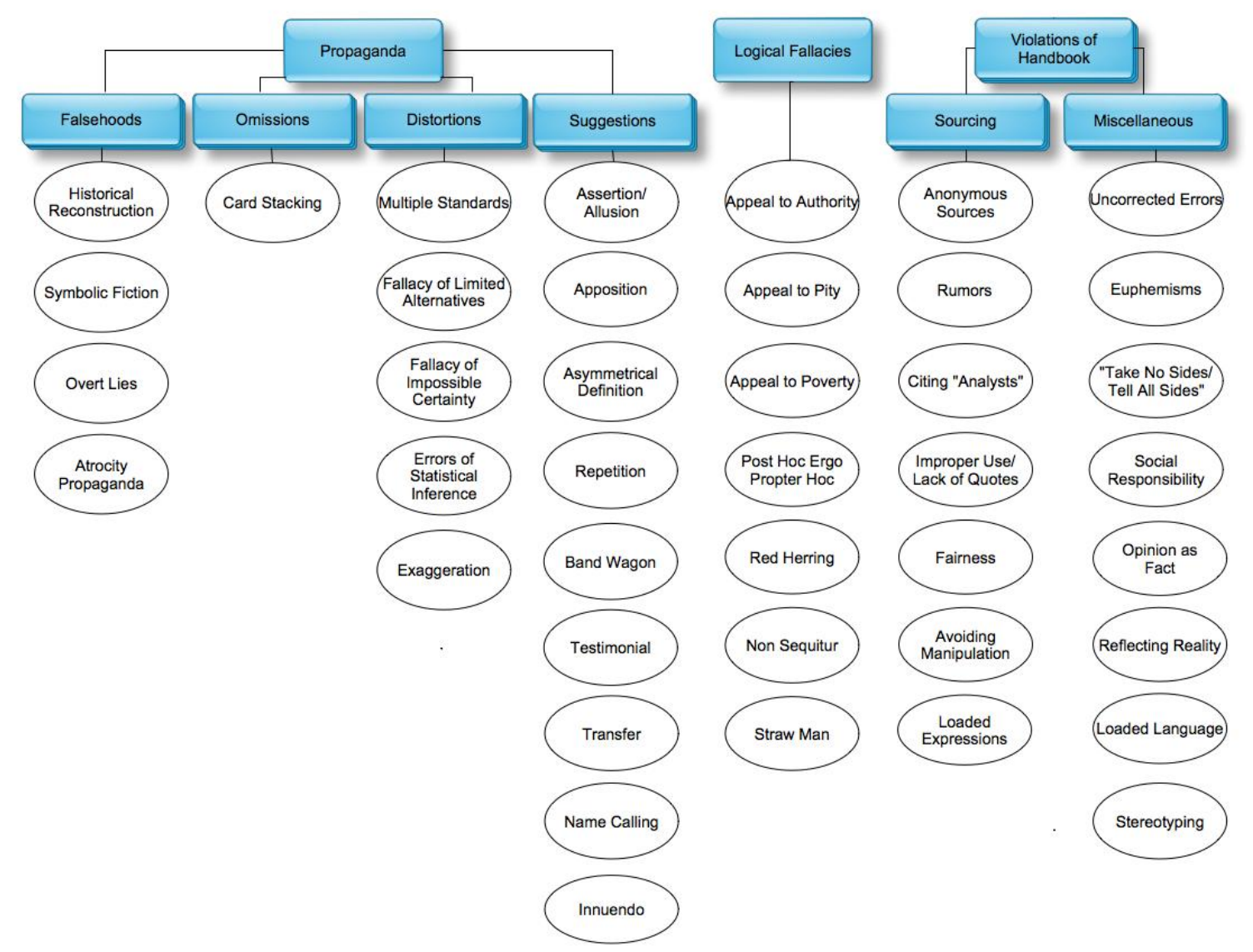

Figure 1: ECA Data Categories And Elements

It was found in this study that many categories could be constructed which met the criteria of "internal homogeneity" and "external homogeneity" as set forth by Guba (1978); the former being demonstrated by the fact that the data within each category dovetailed in a meaningful way, and the latter because in most cases, there is a clear difference between categories, that is, a lack of overlap and duplication. ECA however, allows for data to be assigned to more than one category (Hammersley and Atkinson, 1983; Altheide, 1987) and there are some categories which bear a strong functional relationship to others, e.g., propaganda techniques which also represent a specific, named violation of the Reuters Handbook of Journalism. In such cases, occurrences of the data element have been allocated to both categories. Data generated by the coding system was analyzed using quantitative frequency counts as well as by qualitative narrative data from the text (Smith, Sells, and Clevenger, 1994). Thus, numeric and narrative data are presented concurrently (Altheide, 1985) to support a descriptive interpretation. Validation is supported by the use of examples from the text itself to demonstrate claims (Smith, Sells, and Clevenger, 1994) and through methodological triangulation (Denzin, 1978).

Reliability and validity of claims arising from ethnographic content analysis are supported through intercoder reliability (Smith, Sells, and Clevenger, 1994). This procedure is derived from quantitative content analysis such that categories are tested for reproducibility when coders, unaware of the study purpose, analyze the same text and produce comparable results (Weber, 1990). For this study, a graduate student in clinical psychology was trained in the coding schema listed above and asked to code text from a random sample of stories that had previously been coded. Interrater reliability was assessed using a Scott's phi (Scott, 1955) that varies from 0 to 1 
and corrects for chance agreement. Krippendorff (1980) suggests that a phi reliability score above .80 indicates trustworthy coding for supporting category definitions and drawing inferences. The secondary coder's percentage of agreement with this researcher was .83. When high reliability is achieved, the coding rules can be applied to the entire text (Krippendorff, 1980).

A total of thirty-three university students, undergraduate and graduate, volunteered to participate in the study; all gave their informed written consent prior to inclusion. Subjects were told they were participating in a media study but were not provided details of the purpose of the study. All subjects were initially asked to complete a two-question five-point linear scale survey (neutral = 3) assessing 1) their sympathy/favorable feelings toward one or the other primary belligerent parties in the Middle East conflict, i.e., the Israelis and the Arabs/Palestinians, and 2 ) their motivation to take nonspecific supportive action on behalf of one or the other parties. Subjects were then asked to read individual copies (personal, non-commercial use) of the fifty Reuters stories in the primary data set in chronological sequence and to answer the same two-question survey following each story. The readings and surveys were completed over multiple sessions in a controlled setting, i.e., a classroom. Subjects were asked to try to set aside any preconceived views they may have had on the story topics or subject parties. All survey responses were anonymous and aggregated.

Following data collection, descriptive statistics were generated and tests run comparing mean subject responses for each survey before reading the stories with mean responses following and across the reading of all individual stories. Multivariate regressions were run for each category or sub-category of reporting/ethical failures, i.e., propaganda techniques, logical fallacies, and violations of the Reuters Handbook, with individual reporting/ethical failures serving as independent variables $(X)$ and mean survey results serving as the dependent variable $(Y)$ for each regression.

\section{4. (A) RESULTS AND DISCUSSION}

With respect to research questions 1-3: across the fifty articles in the data sample, ECA reveals 1,104 occurrences of reporting/ethical failures, i.e., propaganda devices, logical fallacies, and violations of the Reuters Handbook of Journalism, with a mean of 22.08 reporting/ethical failures per article. The propaganda device of asymmetrical definition occurs most frequently with a total of 129 instances followed by the propaganda device of card stacking with 94 occurrences. The logical fallacy occurring most frequently is appeal to pity and the Handbook violation occurring with the greatest frequency is that of a failure to uphold social responsibility.

An asymmetrical definition is a type of suggestion where the audience is misled via the propagandist's use of a word or phrase bearing a meaning different than that the audience would normally attribute to it (Smith, 1989). Reuters repetitive use of this technique can be seen in 16 of the sample articles published in June which focus on the story of a Turkish-led flotilla apprehended at sea while attempting to break the Israeli weapons blockade of the Gaza Strip. The flotilla consisted of six vessels, three of which were carrying construction materials and humanitarian aid for Palestinian Arabs (Palestinians) in Gaza. Five of the ships were boarded and subsequently impounded by the Israeli navy without loss of life or serious injury but the sixth ship, the Mavi Marmara, was the scene of violent clashes between passengers armed with cold weapons, e.g., knives and iron bars, and Israeli forces, armed with paintball guns and pistols. ${ }^{12}$ Although it went unreported by Reuters, inspection of the Mavi Marmara cargo hold immediately following the incident revealed no humanitarian aid on board the ship. ${ }^{13}$ Yet, in over a dozen stories in the data sample, Reuters conflates the Mavi Marmara with the other vessels, repeatedly using the word "aid" to describe the ship, its cargo, and its purported mission, i.e., to bring humanitarian aid to Palestinians in Gaza.

In a story published on June 4, $2010^{14}$ for example, Reuters correspondent Tom Perry and then-Jerusalem Bureau Chief Alastair Macdonald write:

\footnotetext{
${ }^{12}$ http://www.nytimes.com/2010/06/05/world/europe/05reconstruct.html?scp=1\&sq=israel+gaza+flotilla+paintball\&st=nyt. Retrieved October 15, 2010.

${ }_{13}^{13}$ http://www.turkel-committee.gov.il/index-eng.html. Retrieved February 3, 2011.

14 "Analysis-Israel to give tactical ground to Gaza pressure". http://in.reuters.com/article/2010/06/04/idINIndia49047420100604. Retrieved September 2, 2010. 
Israel is unlikely to heed calls to lift the blockade of the Gaza Strip but is bloody seizure of a Turkish aid ship has caused international anger and American dismay that is forcing it to seek conciliatory moves. [italics mine]

Israel's leaders have been unrepentant. Prime Minister Netanyahu accused Europeans of "hypocrisy" over efforts to stop Iranian arms reaching Gaza's Hamas Islamist rulers. [italics mine]

But even with vital ally the United States criticizing the harm the blockade is doing to the 1.5 million Palestinians in Gaza, and President Barack Obama calling the killing of nine men, including an American, a tragedy, Netanyahu is seeking points where concessions can soak up some of the pressure. [italics mine]

Perry and Macdonald's de facto editorial piece, which is identified in the headline as "Analysis" rather than with the more traditional and transparent term "Op-Ed" adopted by most media firms for stories where subjective content appears, is laden with propaganda devices and violations of the Reuters Handbook of Journalism.

First, by mischaracterizing the Mavi Marmara as an "aid ship", asymmetrical definition is being deployed to suggest a role for the ship distinctly different from the role it actually undertook and ultimately played in the incident. Although it is remotely possible Perry and Macdonald are utilizing the word "aid" to mean assistance in a socio-political sense, i.e., calling attention to the circumstances of Palestinians living in Gaza, readers are clearly and overtly being given the false impression that the Mavi Marmara carried humanitarian aid when it did not.

The statement, "Israel's leaders have been unrepentant" reflects both the propaganda device of innuendo and the use of loaded words, a violation of Reuters Handbook ${ }^{15}$, as the language implicitly conveys a judgment of wrongdoing and moral condemnation of Israel's government officials for the incident which had neither been alleged nor proven by any juridical body.

"The harm the blockade is doing to the 1.5 million Palestinians in Gaza" reflects 1) an assertion; 2) exaggeration; 3) card stacking; and 4) atrocity propaganda respectively, as the phrase is 1) unproven; 2) inflates the impact of the "blockade" to encompass the entire population in Gaza; 3) omits mention of the fact that Egypt too, had been embargoing the Gaza Strip ${ }^{16}$; and 4) alludes to the "blockade" as a war atrocity by virtue of its alleged deleterious effect on the civilian population, without mentioning that all manner of humanitarian goods had been regularly transiting through the Israeli land border with the Gaza Strip. ${ }^{17}$

Perry and Macdonald then cite President Barack Obama "calling the killing of nine men, including an American, a tragedy". What Obama actually said in the relevant interview with CNN one day prior to the publication of the Reuters story was the following:

What's important right now is that we break out of the current impasse, use this tragedy as an opportunity so that we figure out how can we meet Israel's security concerns, but, at the same time, start opening up opportunity for Palestinians, work with all parties concerned, the Palestinian Authority, the Israelis, the Egyptians, and others. And I think Turkey can have a positive voice in this whole process, once we've worked through this tragedy, and bring everybody together to figure out, how can we get a two-state solution where Palestinians and the Israelis can live side-by-side in peace and security. ${ }^{18}$

Note that Obama characterizes as a "tragedy" the incident generally, i.e., the violence and casualties on both sides, not the "[Israeli] killing of nine men, including an American" as Perry and Macdonald misstate. This reporting failure is, at a minimum, an uncorrected error and improper use/lack of quotes, both violations of the

\footnotetext{
${ }_{15}^{15} \mathrm{http} / / /$ handbook.reuters.com/index.php/Reporting_about_people\#Social_responsibility. Retrieved October 18, 2010.

${ }_{16}$ http://www.bloomberg.com/news/2011-04-29/egypt-may-open-border-to-gaza-strip-within-two-weeks-in-a-rebuff-toisrael.html. Retrieved May 2, 2011.

${ }^{17}$ http://www.mfa.gov.il/MFA/Government/Communiques/2009/Increased_humanitarian_aid_Gaza_after_IDF_operation_Jan_20 09.htm. Retrieved February 4, 2011.

${ }^{18}$ http://archives.cnn.com/TRANSCRIPTS/1006/03/lkl.01.html. Retrieved February 4, 2011.
} 
Reuters Handbook. ${ }^{19}$ More likely, given the easily accessible record of the President's televised comments just a day earlier, the mischaracterization reflects a historical reconstruction, i.e., intentional fabrication, on the part of Perry and Macdonald.

In a particularly egregious example of card stacking and historical reconstruction reminiscent of the Lebanese doctored photo scandal discussed in the introduction to this paper, Reuters publishes a large captioned photo on May 31, 2010 depicting an injured Israeli commando being held down by passengers on board the Mavi Marmara during the violent incident discussed above. The original photo was taken by a passenger on the ship and published on the website of the Turkish Islamist group, Insani Yardım Vakfi (IHH), which sponsored the Gaza flotilla. In a comparison between the original photo and that published by Reuters, one notes the Reuters version has been materially cropped, excising a serrated knife held by one of the passengers, a pool of blood, and another injured Israeli commando prostrate on the floor. A violation of the Reuters Handbook, the cropping removed contextually essential information, i.e., evidence of the weapons held and deployed by passengers against the Israelis, thus effectively censoring the facts revealed by the original photo. Reuters has since acknowledged the photo manipulation but insists that this had been "normal editorial practice". 20

On July 2, 2010 Reuters ran a story entitled “Gaza Siege Damages Palestinians' Health: Study" which cites, second-hand, Palestinian researchers and data drawn from a series of studies published in the Lancet medical journal on the same day. Reuters' story contains 4 occurrences of atrocity propaganda including the suggestion that Israel's embargo on the Gaza Strip was putting Palestinian children at risk of stunted growth and malnutrition. As alleged evidence of this, Reuters cites a study of 2,000 children and adolescents in Gaza showing that one in four misses breakfast (the article does not state whether this occurs everyday), 2 percent are underweight, and 1 in 17 is stunted. Reuters fails to inform readers that in affluent countries like the US for example, breakfast is not eaten all the time by 42 percent to 59 percent of children ${ }^{21}$ and nearly 4 percent are underweight. ${ }^{22}$ Moreover, the rate of stunting in Gaza is the second lowest in the Arab world. ${ }^{23}$

In the same story, Reuters cites "Palestinian health experts" alleging that the destruction of Palestinian infrastructure, including homes, as a result of the 2008-09 Gaza war was "unprecedented". Statistics provided by Reuters in the same story indicate that of 3,000 Gaza households randomly surveyed, 39 percent of "almost a third" of the sample population, i.e., a maximum of just over 12 percent, had their residences either completely or "partly" destroyed in the war. There is no amplification beyond the characterization "partly". By way of comparison, 3.6 million or 20 percent of homes in Germany were bombed to rubble during World War II; ${ }^{24} 25$ percent of all British homes were destroyed or made unlivable during the same. ${ }^{25}$ It is gross hyperbole, if not calumny, to describe the alleged 12 percent of residential property damaged to some extent in Gaza as "unprecedented".

Although this paper is focused on Reuters' synopsis of the original study in the Lancet medical journal and that study has not been reviewed for validity by this writer, it should also be noted that the Lancet has, in the past, published studies that have been shown to be seriously flawed and in at least one case, fraudulent. ${ }^{26}$

In a de facto Op-Ed published as "Analysis" on August 30, 2010"27, "Analysis-To Palestinians, third intifada as unlikely as peace", Reuters correspondent Tom Perry employs the asymmetrical definition device nine times, with six occurrences of the word "uprising" to describe for his audience, the Intifada or Oslo War, a seven-year period of

${ }^{19} \mathrm{http} / / /$ handbook.reuters.com/index.php/Accuracy\#Corrections. Retrieved October 18, 2010.

${ }^{20} \mathrm{http://blogs.reuters.com/gbu/2010/06/07/cropped-photos/.} \mathrm{Retrieved} \mathrm{September} \mathrm{17,} 2010$.

21 http://www.eatright.org/Media/content.aspx?id=6442459600. Retrieved February 23, 2011.

22 http://www.cdc.gov/nchs/data/hestat/underweight_child_07_08/underweight_child_07_08.htm. Retrieved February 23, 2011.

23 http://www.unicef.org/rightsite/sowc/statistics.php. Retrieved February 23, 2011.

${ }^{24} \mathrm{http}: / /$ www.nazi.org.uk/military\%20pdfs3/AfterTheReich-TheBrutalHistoryOfTheAlliedOccupation.pdf. Retrieved February $23,2011$.

${ }^{25}$ http://clio.missouristate.edu/tsdicke/untitled 7.htm. Retrieved February 23, 2011.

26 "Journal: Study Linking Vaccine to Autism Was Fraud". http://www.aolnews.com/2011/01/05/lancet-journal-andrewwakefield-study-linking-vaccine-to-autis/. Retrieved February 23, 2011.

27 “Analysis-To Palestinians, third intifada as unlikely as peace". http://www.reuters.com/article/2010/08/30/us-palestiniansisrael-stability-idUSTRE67S1DA20100830. Retrieved September 2, 2010. 
lethal urban violence between Israel and the Palestinians that commenced in 2000. From the Arabic intifasza, meaning "revolt", Perry's innocuous reference to "uprising" effectively conceals and sanitizes the horrific reality of a war which produced a total of more than ten thousand killed and wounded combatants and civilians. The references to "uprising" have thus been cross-coded under ECA as euphemisms, the use of which represents a violation of professional journalistic guidelines as specified in the Reuters Handbook. ${ }^{28}$ The true nature and magnitude of the war can only be apprehended when Perry cites casualty statistics:

Over 500 Israeli civilians died in 140 Palestinian suicide bomb attacks from 2000 to 2007. More than 4,500 Palestinians were killed by Israeli forces in the same period.

Even here however, serious reporting failures occur. In an instance of card stacking, Perry includes all Palestinians killed by any means but willfully excludes Israeli security personnel and those Israelis killed by means other than suicide bomb attacks. When these groups are included, the number of Israelis killed rises to more than double Perry's appraisal. ${ }^{29}$ And note how Perry describes the Israelis as having (passively) "died" while Palestinians were (actively) "killed". The use of the word "died" here reflects another euphemism, and the asymmetric distorting of the casualty figures represents the propaganda device of error of statistical inference as well as being a violation of the Reuters' Handbook admonition to its journalists to take no side, tell all sides. ${ }^{30}$

Another euphemism and asymmetrical definition employed by Perry in the same story can be found in the following paragraph:

The uprising erupted when [President] Clinton failed to forge a deal between the late Palestinian leader Yasser Arafat and Ehud Barak, then Israel's prime minister. Palestinian leaders at the time declared the Intifada as the route to liberation. [italics mine]

Merriam-Webster defines liberation as "a movement seeking equal rights and status for a group" ${ }^{\text {"31 }}$ and readers, particularly those living in a Western society, are likely to interpret Perry's reference within this context. The word liberation has a very different meaning however, for Arab-Muslims engaged in military conflict with Israel and the West. Hamas for example, the militant Palestinian group currently in power in the Gaza Strip and supported by millions of Palestinians, maintains a Charter which serves as a Mission statement for the organization. The Introduction to the Hamas Charter sets out its aims and methods:

...the Islamic Resistance Movement erupted in order to play its role in the path of its Lord. In so doing, it joined its hands with those of all Jihad fighters for the purpose of liberating Palestine. The souls of its Jihad fighters will encounter those of all Jihad fighters who have sacrificed their lives in the land of Palestine since it was conquered by the Companion of the Prophet, be Allah's prayer and peace upon him, and until this very day. This is the Charter of the Islamic Resistance (Hamas) which will reveal its face, unveil its identity, state its position, clarify its purpose, discuss its hopes, call for support to its cause and reinforcement, and for joining its ranks. For our struggle against the Jews is extremely wide-ranging and grave, so much so that it will need all the loyal efforts we can wield, to be followed by further steps and reinforced by successive battalions from the multifarious Arab and Islamic world, until the enemies are defeated and Allah's victory prevails. ${ }^{32}$ [italics mine]

Clearly, Palestinian leaders and a sizeable portion of the Palestinian electorate have a distinctly different view of the notion of "liberation" than that suggested by Perry and understood by Western audiences.

\footnotetext{
${ }^{28} \mathrm{http}: / /$ handbook.reuters.com/index.php/E\#euphemism. Retrieved October 19, 2010.

${ }_{29} \mathrm{http}: / /$ www.mfa.gov.il/MFA/Terrorism-,

+Obstacle+to+Peace/Palestinian+terror+since+2000/Victims+of+Palestinian+Violence+and+Terrorism+sinc.htm. Retrieved March 11, 2011.

${ }^{30} \mathrm{http}$ ///handbook.reuters.com/index.php/Freedom_from_bias\#Take_no_side.2C_tell_all_sides. Retrieved October $18,2010$.

${ }_{31} \mathrm{http} / / / \mathrm{www} . m e r r i a m-w e b s t e r . c o m / d i c t i o n a r y /$ liberation. Retrieved April 13, 2011.

32 http://www.thejerusalemfund.org/www.thejerusalemfund.org/carryover/documents/charter.html. Retrieved April 13, 2011.
} 
As indicated above, the logical fallacy occurring most frequently across the data sample is appeal to pity. This fallacy consists of emotionally-charged images or language intended to evoke sympathy ${ }^{33}$ and manipulate an audience into adopting a partisan view or supporting an interest group. A particularly rich example of this reporting failure can be seen in a Reuters story published on June $1,2010^{34}$ about the Turkish flotilla bound for Gaza discussed earlier in this section. Although more than 85 percent of the story content consists of quotes from passengers promoting their version of the incident and no comments from Israeli officials or military personnel participating in the operation are provided (a violation of the Reuters Handbook ${ }^{35}$ ), Reuters headlines its story with the presumptive title "Factbox". Following this, is an overt lie and non sequitur:

Israel has detained some 700 activists incommunicado, ensuring no contradiction of its version of events. [italics mine]

Reuters then proceeds to quote five of the passengers contradicting Israel's version of events[!]. The passenger comments are laden with emotional accounts of violations of international law, including alleged atrocities, by Israeli commandos. Passenger Mutlu Tiiryaki for example, asserts:

When we went up to the deck, they emerged from helicopters and military boats and attacked us. They approached our vessel with military ships after issuing a warning. We told them that we were unarmed. Our sole weapon was water.

In this instance of card stacking, Reuters fails to report that Tiryaki was not actually a passenger on the Mavi Marmara, the ship where passengers met and assaulted Israeli commandoes with knives and iron bars. ${ }^{36}$ Moreover, nowhere in the story does Reuters interview or provide alternative testimony from Israelis, several of whom were severely beaten, knifed and immobilized by passengers as documented by video footage and photographs taken by both Israeli military sources and the passengers themselves as noted earlier. ${ }^{37}$

On August 3, 2010, an Israeli military maintenance crew was paring tree branches on the Israeli side of the "Blue Line", the official United Nations border demarcation between Israel and Lebanon to its north, when Lebanese troops opened fire on the crew and security positions on the Israeli side of the border killing an Israeli officer and seriously wounding another. Israeli forces immediately retaliated, killing a Lebanese army sergeant. The following day, Reuters published a captioned photo of the daughter of the dead Lebanese soldier, crying at his funeral. In this example of the logical fallacy of appeal to pity, the propaganda technique of card stacking, and the Handbook violation of take no side/tell all sides, Reuters elicits sympathy for the Lebanese soldier and his family while providing no balancing depiction of Israeli familial losses, despite the fact that the Lebanese military initiated the violence resulting in the fatalities.

Reuters Handbook of Journalism stipulates that its correspondents uphold a strict policy of social responsibility by providing complete facts, all sides of an argument and relevant context in neutral prose. ${ }^{38}$ As part of this responsibility, Reuters admonishes its journalists:

We must be on alert for language that could imply support for one side of a conflict, sympathy for a point of view, or an ethnocentric vantage point. We should, for example, provide the dual names of disputed territories. We must not parrot any loaded expressions used by our sources, except in quotes and official titles. Generic references to a specific country as "the homeland" for example, are unwelcome.

\footnotetext{
${ }^{33} \mathrm{http}: / /$ www.logicalfallacies.info/relevance/appeals/appeal-to-pity/. Retrieved November 20, 2010.

34 "Factbox: Comments from activists on Gaza aid convoy". http://www.reuters.com/article/2010/06/01/us-palestinians-israelturkey-testimony-idUSTRE6501DP20100601. Retrieved September 2, 1010.

${ }^{35} \mathrm{http} / / /$ handbook.reuters.com/index.php/Freedom_from_bias\#Take_no_side.2C_tell_all_sides. Retrieved October 19, 2010.

${ }^{36}$ http://www.todayszaman.com/news-211761-100-passenger-on-aid-flotilla-describes-israeli-attack.html. Retrieved March 12, 2011.

${ }^{37} \mathrm{http}: / /$ www.mfa.gov.il/MFA/Government/Communiques/2010/Israel_Navy_warns_flotilla_31-May-2010.htm. Retrieved March 12, 2011.

${ }^{38}$ http://handbook.reuters.com/index.php/Reporting_about_people\#Social_responsibility. Retrieved October 18, 2010. 
As demonstrated by 75 occurrences across the data sample, Reuters regularly violates this policy in its Middle East reporting. In a story published on its website on July 7, $2010^{39}$ "Palestinians wary of direct peace talks with Israel", correspondents Ali Sawafta and Douglas Hamilton refer to the last unallocated portion of the Palestine Mandate as the "West Bank" seven times. The appellation "West Bank" was assigned to the territory in 1949 by the Arabs of Jordan (then "Transjordan") following their invasion, conquest, and illegal occupation of the land and associated ethnic cleansing of Jewish communities from the area. ${ }^{40}$ The acknowledged Israeli-Judeo name for the disputed territory is Judea and Samaria, any reference to which is notably absent from Sawafta and Hamilton's story. This asymmetric handling falsely suggests Jordanian or Arab sovereignty of the land, underscores Reuters' Arab ethnocentric vantage point, and thus, the agency's support for the Arab side of the conflict.

Similarly, Sawafta and Hamilton cite Palestinian President Mahmoud Abbas’ aide Nabil Abu Rdainah:

In talks mediated by former U.S. Secretary of State Condoleeza Rice the Israelis acknowledged that occupied land means the Gaza Strip, the West Bank, Arab East Jerusalem, the Dead Sea and the Jordan Valley, [Palestinian President Mahmoud Abbas' aide] Abu Rdainah said.

In violation of the Reuters Handbook, Sawafta and Hamilton parrot the term "West Bank" and the loaded expression "Arab East Jerusalem", again revealing a distinctly Arab ethnocentric vantage point. Moreover, no Israeli source is cited that might otherwise contravene Abu Rdainah's assertion that Israel had acknowledged these areas as "occupied", a violation of the fairness doctrine of Reuters Handbook ${ }^{41}$. Indeed, as Israel claims all of Jerusalem under its sovereignty, it is highly unlikely any Israeli official would refer to the eastern portion of Jerusalem as "Arab East Jerusalem", the reference to which also reflects a historical reconstruction ${ }^{42}$.

Another historical reconstruction in the same story includes Sawafta and Hamilton's assertion ${ }^{43}$ that:

Direct talks with the previous Israeli government of Ehud Olmert collapsed when Israel bombed the Gaza Strip 18 months ago to suppress rocket fire from Palestinian Islamists headed by the Hamas movement, which rejects a peace treaty with Israel.

In fact, peace talks between Israel and the Palestinian Authority had effectively ended weeks prior to the Gaza War as a result of Palestinian President Mahmoud Abbas' rejection of a settlement offer from Israeli Prime Minister Ehud Olmert ${ }^{44}$ and failed Palestinian efforts to persuade world powers constituting the Quartet to agree to coerce Israel to accept a Palestinian state on all disputed territory with a Palestinian capital in the eastern portion of Jerusalem. ${ }^{45}$ Sawafta and Hamilton fabricate a false association here between the war and the breakdown of negotiations.

Finally, employing a propaganda device known as symbolic fiction ${ }^{46}$, Sawafta and Hamilton cite a study by an Israeli non-government organization:

\footnotetext{
39 "Palestinians wary of direct peace talks with Israel". http://www.reuters.com/article/2010/07/07/us-palestinians-israelidUSTRE6662NH20100707. Retrieved September 2, 2010.

${ }^{40} \mathrm{http}: / /$ www.mideastweb.org/Middle-East-Encyclopedia/west_bank.htm. Retrieved November 4, 2010.

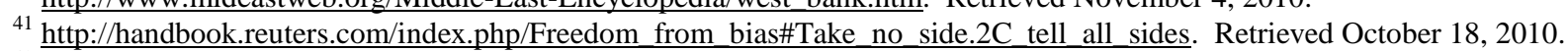

${ }^{42}$ http://news.bbc.co.uk/2/hi/in_depth/middle_east/israel_and_the_palestinians/key_documents/6044090.stm\#east\%20jerusalem. Retrieved November 4, 2010.

${ }^{43}$ http://library.thinkquest.org/C0111500/proptech.htm. November 19, 2010.

${ }_{44} \mathrm{http}$ ://www.washingtonpost.com/wp-dyn/content/article/2009/05/28/AR2009052803614.html. Retrieved February 14, 2011.

45 http://www.reuters.com/article/2008/11/02/idUSL2313081. Retrieved September 2, 2010.

${ }^{46}$ http://books.google.com/books?id=YMQjDiHYggcC\&pg=PA155\&lpg=PA155\&dq=propaganda+\%22symbolic+fiction\%22\&s ource=bl\&ots=Z9BCHIAeUX\&sig=czx6reD4QcJRnvTiK6tafhL4obY\&hl=en\&ei=4u3STeWMLafz0gGfm73NCw\&sa=X\&oi=b ook result\&ct=result\&resnum $=5 \& \mathrm{ved}=0 \mathrm{CDMQ}$ AEwBA\#v $=$ onepage $\& \mathrm{q}=$ propaganda $\% 20 \% 22 \mathrm{symbolic} \% 20 \mathrm{fiction} \% 22 \& \mathrm{f}=\mathrm{fals}$ e. Retrieved October 12, 2010.
} 
A report this week by Israeli human rights group B'Tselem says more than 300,000 Israelis now live on 42 percent of the West Bank, land where Palestinians want to establish their future country in a "two-state solution" with Israel.

The B'Tselem study does not say this. Rather, the report indicates that Jewish communities reside upon less than 1 percent of this disputed territory. There is an allegation that due to the classification of a portion of the territory as "state land" by Israel, 42 percent of it is controlled by Israeli Jewish councils. ${ }^{47}$ Even this claim however, has been rejected by the Chairman of the Council of Jewish Communities who puts the figure at 9 percent. ${ }^{48}$ Following presentation of this fiction, Sawafta and Hamilton again violate Reuters' fairness doctrine by failing to provide space for any Israeli official to respond to the fictionalized claim in their story.

\section{4. (B) RESULTS AND DISCUSSION}

To address the questions of whether Reuters stories on the Middle East conflict influence readers to feel more sympathetic/favorable toward one or the other belligerent parties and/or to feel more motivated to take some supportive action on behalf of one or the other belligerent parties (research questions 4 and 5 respectively), mean subject attitudes before reading the stories are compared with mean subject attitudes following and across the reading of all individual stories. To adjust for differences in variances between the two temporal populations and with no assumption of Gaussian distributions, mean values are logarithmically transformed and we perform a nonparametric Mann-Whitney Test. Results are shown in Table 1.

For both survey questions, there is a large and extremely significant difference between the mean subject response prior to undertaking the readings and the mean response following the individual readings. With respect to research question 4, on average, subjects take a largely neutral view of the belligerents going into the study (untransformed mean 3.18) but substantially shift their view in favor of the Arabs/Palestinians over the course of the readings (untransformed mean 2.17). Similarly, with respect to research question 5, prior to the readings subjects are nearly dead neutral on whether they feel motivated to take supportive action on behalf of one or the other belligerent parties (untransformed mean 3.12) but over the course of the readings, subjects feel significantly more motivated to take supportive action on behalf of the Arabs/Palestinians (untransformed mean 2.35).

Consistent with the findings of Likert (1932), Rosenthal (1934), and other researchers employing linear scales to measure the effect of propaganda on audience attitudes and behavior, Reuters' stories are clearly influencing reader sentiment, in this case by shifting it favorably toward the Arabs/Palestinians and away from the Israelis. The magnitude of this shift is greater in the case of Survey Question 1 than for Survey Question 2, which might be expected given that the former reflects primarily affective behavior, i.e., emotional reactions, while the latter implicitly involves overt behavior, that which requires conscious action and is readily observable (Triandis, 1977). The findings suggest it is easier to influence audience emotion than action-oriented decisions, a reasonable expectation.

Table 1: Mean Subject Attitudes/Support Before Readings/After Readings

\begin{tabular}{|l|c|c|}
\hline \multicolumn{2}{|c|}{ Parameter } & Survey 1 \\
\hline N & 33 & After Readings \\
Untransformed Mean & 3.18 & 2.17 \\
Untransformed SD & 0.73 & 0.44 \\
Log-transformed Mean & 1.13 & 0.75 \\
Log-transformed SD & 0.27 & 0.24 \\
Log-transformed SE & 0.05 & 0.04 \\
Lower 95\% CI & 1.03 & 0.66 \\
Upper 95\% CI & 1.22 & 0.83 \\
\hline
\end{tabular}

Note. Neutral = 3. Mann-Whitney U-statistic $=55.50$. U' $=1033.5$.

${ }^{47} \mathrm{http}: / /$ www.btselem.org/English/Publications/Summaries/201007 By Hook and by Crook.asp. Retrieved February $15,2011$.

48 http://www.jpost.com/International/Article.aspx?id=180563. Retrieved February 15, 2011. 
Table 1: Mean Subject Attitudes/Support Before Readings/After Readings (Continued)

\begin{tabular}{|l|c|c|}
\hline \multicolumn{1}{|c|}{ Parameter } & Survey 2 & After Readings \\
\hline $\mathrm{N}$ & 33 & 33 \\
Untransformed Mean & 3.12 & 2.35 \\
Untransformed SD & 0.60 & 0.47 \\
Log-transformed Mean & 1.12 & 0.83 \\
Log-transformed SD & 0.24 & 0.23 \\
Log-transformed SE & 0.04 & 0.04 \\
Lower 95\% CI & 1.03 & 0.75 \\
Upper 95\% CI & 1.20 & 0.91 \\
\hline
\end{tabular}

Note. Neutral $=3$. Mann-Whitney U-statistic $=33.00$. U' $=1056.0$.

A critical question is whether these shifts in reader attitudes/support are due simply to a fair presentation of the facts, or whether Reuters correspondents' documented use of propaganda, logical fallacies, and violations of the Reuters Handbook is driving the observed shifts. This is addressed by triangulating, i.e., testing for associations between the specific reporting/ethical failures identified by ECA, and reader attitudes as reflected in the survey data (research questions 6 and 7, respectively).

To avoid overfitting the data, the reporting/ethical failures identified in Section 4. (A) are divided into five groups for multivariate regression analysis: 1) Propaganda: Falsehoods, Omissions, Distortions; 2) Propaganda: Suggestions; 3) Logical Fallacies; 4) Handbook Violations: Sourcing; 5) Handbook Violations: Miscellaneous. Mean survey responses for stories in the sample serve as the dependent variable and reporting/ethical failures in each story serve as the independent variables. Separate regressions are run for each of the two survey questions. Regression results are shown in Table 2. R-squared values between $X$ variables are low indicating they are independent of one another, i.e., multicollinearity is not an issue.

There is a highly significant and negative association between propaganda (Falsehoods, Omissions, Distortions) appearing in the sample stories and reader responses to each of the survey questions. Specifically, as the frequency of atrocity propaganda increases, subject responses shift toward the lower end of the scale, i.e., become increasingly favorable/sympathetic toward the Arabs/Palestinians. Similarly, an increase in atrocity propaganda motivates subjects to take supportive action on behalf of the Arabs/Palestinians. These results strongly suggest that when atrocity propaganda is employed by Reuters (32 occurrences across the sample), it is typically arrayed against the Israelis, i.e., the Israelis are portrayed as the offending party committing atrocities against the Arabs/Palestinians.

One can readily observe this skew in the July 2, 2010 Reuters story entitled "Gaza Siege Damages Palestinians' Health: Study" where readers responded to the first survey question with a mean score of 1.74, nearly two standard deviations below the sample mean, and to the second survey question with a mean score of 1.58 , the lowest across the sample. The story, analyzed in Section 4. (A) of this paper contains 4 occurrences of atrocity propaganda including the citing of "Palestinian health experts" alleging, falsely, that the destruction of Palestinian infrastructure and homes as a result of the Gaza war in 2009 was "unprecedented" and further misleading readers with dubious and decontextualized figures to suggest that Israel's "blockade" of the Gaza Strip was putting Palestinian children at risk of stunted growth and malnutrition. Moreover, the story is devoid of any balancing narrative or data associated with the ill effects on Israeli civilians, particularly children, ${ }^{49}$ of Palestinian rocket and mortar attacks originating from Gaza which precipitated the Israeli embargo of specified goods into the territory.

Although Reuters is not a recognized belligerent in the Middle East conflict, the agency's use of (onesided) atrocity propaganda to influence its audience may be viewed as a form of psychological warfare as defined by Lineberger (1954) in that it is successfully driving attitude changes and motivating its readership to take direct action to support one of the belligerents, the Arabs/Palestinians, in response to stories of "inhuman acts" allegedly perpetrated by the Israelis. This is akin to the purpose, content, and success of atrocity propaganda circulated by both the Allies and Germany during the first world war (Jowett and O'Donnell, 1999).

${ }^{49}$ http://www.ynetnews.com/articles/0,7340,L-3739071,00.html. Retrieved February 17, 2011. 
Table 2: Relationships Between Reporting Failures And Mean Survey Responses

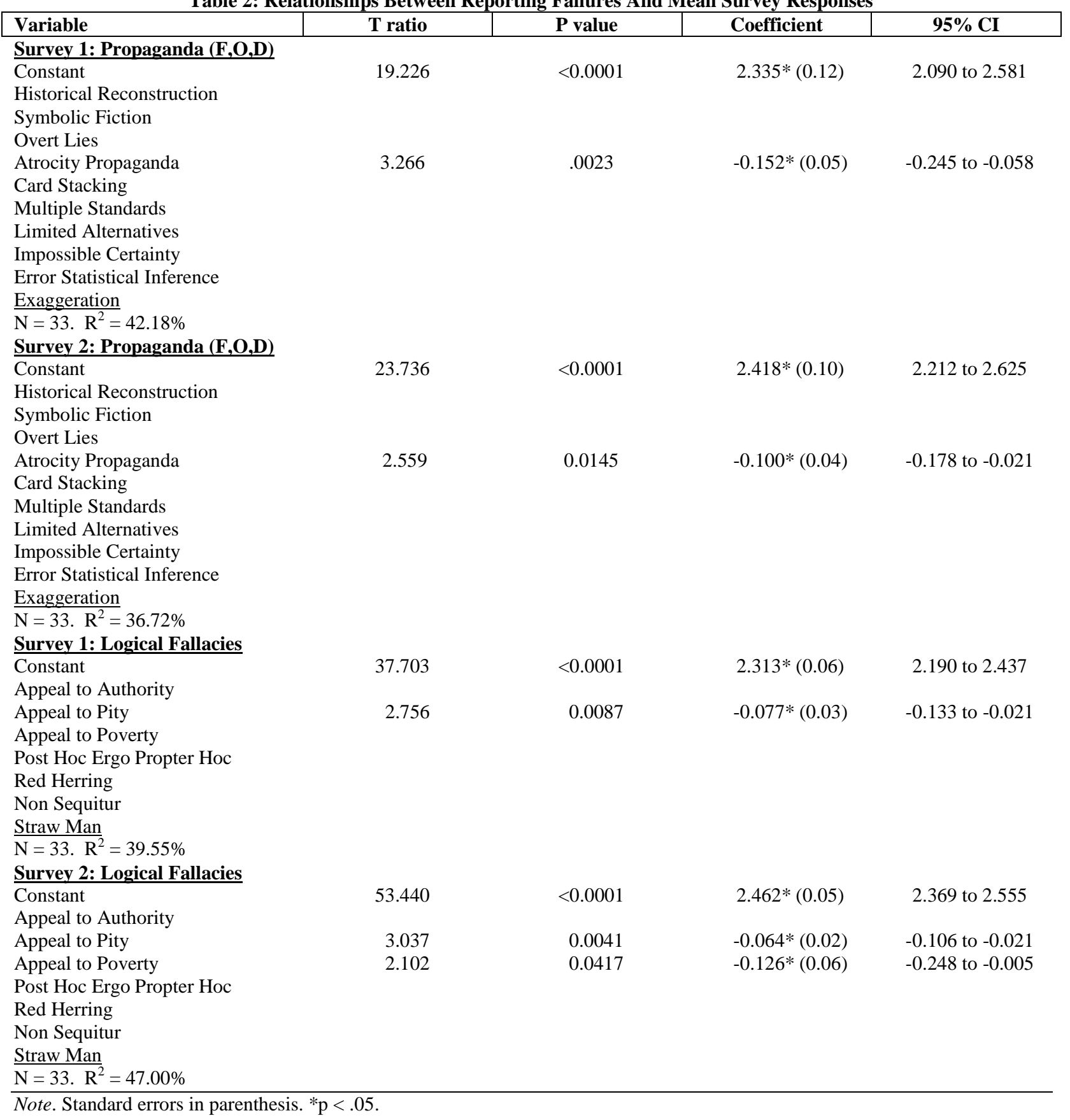

The $\mathrm{P}$ value produced by the regression model testing for associations between propaganda (Suggestions) and subject survey responses is insignificant at the 5\% level, precluding us from drawing inferences about the power of these reporting/ethical failures to influence readers.

For the regressions involving logical fallacies, $\mathrm{P}$ values are extremely significant and the coefficients for appeal to pity are significant and negative in both equations; that is, the more frequently the appeal to pity fallacy appears in the material (64 occurrences), the greater subjects are moved to view the Arabs/Palestinians favorably/sympathetically and the more subjects are motivated to take supportive action on behalf of this belligerent. 
The regression for Survey Question 2 also yields a significant and negative coefficient for appeal to poverty; as the use of this logical fallacy increases, subjects are motivated to take greater supportive action on behalf of the Arabs/Palestinians. As in the case of atrocity propaganda, the favorable audience shift towards the Arabs/Palestinians associated with the occurrences of appeal to pity and appeal to poverty strongly suggests that when these devices are employed by Reuters, it is the Arabs/Palestinians who are portrayed as victimized (by the Israelis) and impoverished and thus, worthy of reader sympathy and supportive action.

An illustration of this indicated bias can be seen in the July 27, 2010 Reuters story "Gazans Want 'Marshall Plan', Israel Policy Falls Short" which contains 9 occurrences of appeal to pity and 6 occurrences of appeal to poverty, drawing a mean reader score of 1.73 for the first survey question (two standard deviations below the mean) and a mean score of 1.88 for the second survey question, both reflecting heavily favorable sentiment toward the Arabs/Palestinians. The story paints a bleak picture of the Gazan economy and living conditions in the territory, particularly poverty rates, and portrays Israel as the culprit ("blockade has destroyed industries and hope"). In a story of nearly 1,100 words, Reuters correspondent Tom Perry devotes just 5 words to reporting on the (thousands of) Palestinian rocket attacks on Israeli civilian communities ${ }^{50}$ precipitating the selective Israeli embargo of Gaza. Entirely omitted from the story is any discussion of Israeli poverty rates - approximately one fifth of all under-age children in the country suffer from hunger ${ }^{51} ; 75$ percent of impoverished families cannot afford medicine and 70 percent are dependent on food donations ${ }^{52}$ - which are a result, in large part, of extraordinarily high levels of military spending ${ }^{53}$ associated with defense against the very rocket attacks of which Perry offers only cursory mention.

$\mathrm{P}$ values produced by the regression models testing for associations between violations of the Reuters Handbook and subject survey responses are insignificant at the 5\% level, precluding us from drawing inferences about the power of these violations to influence readers.

The final question for study asks what can be inferred about the ideology and purpose of Reuters Middle East reporting from the data. With its much vaunted Trust Principles and Handbook of Journalism, Reuters would have us believe that its reporting on the Arab/Israeli conflict is consistent with the agency's commitment to "integrity, independence, and freedom from bias" $" 54$ and that its correspondents and editors in this area are making all efforts "to search for and report the truth, fairly, honestly, and unfailingly" ${ }^{\text {"55 }}$, i.e., to adhere to the highest ethical standards of professional journalism.

Yet, the findings reveal a radically different journalistic approach and product and suggest a very different set of objectives for the agency. The enormous number of reporting/ethical failures in the form of propaganda devices, logical fallacies, and violations of the Reuters Handbook seen in the story sample, the largely asymmetric nature of these failures, and the demonstrated ability to powerfully shape reader attitudes and motivate direct action via the deployment of atrocity propaganda, appeals to pity and appeals to poverty, provide strong evidence of an ideology which is heavily partisan, i.e., supportive of the Arabs/Palestinians, and an explicit purpose to systematically disseminate that ideology and manipulate audiences to adopt the same. This would be a clear violation of Reuters' ethical charter, the Trust Principles, as well as the ethical and professional guidelines set out in the Reuters Handbook.

This study provides only a window into the inner ideological and editorial workings of the largest international news agency in the world. As Sproule (1994) suggests, the intent of the propagandist is often covert. Powerful evidence of that intent has been presented here but to fully reveal, understand and delineate the objectives,

\footnotetext{
${ }^{50}$ http://www.mfa.gov.il/MFA/Terrorism+ +Obstacle+to+Peace/Palestinian+terror+since+2000/Missile+fire+from+Gaza+on+Israeli+civilian+targets+Aug+2007.htm. Retrieved March 17, 2011.

${ }^{51}$ http://www.wsws.org/de/2006/mai2006/js2-m20.shtml. Retrieved February 17, 2011.

52 http://www.socwork.net/2007/2/essays/michelschertges/Debate MichelSchertges.pdf. Retrieved February 17, 2011.

${ }_{53} \mathrm{http://www.defensenews.com/story.php?i=6060108.} \mathrm{Retrieved} \mathrm{March} \mathrm{27,} 2011$.

${ }_{54} \mathrm{http://thomsonreuters.com/about/trust \_ principles/.} \mathrm{Retrieved} \mathrm{September} \mathrm{1,} 2010$.

55 http://handbook.reuters.com/index.php/Main Page. Retrieved October 18, 2010.
} 
beliefs, values and motivations of Reuters correspondents, editors and managers, it may ultimately be necessary for researchers to elicit this information directly from the journalists themselves.

\section{CONCLUSION}

This paper examines a sample of fifty news-oriented articles related to the Middle East conflict published on the Reuters proprietary websites across a three month study window. A combination of Ethnographic Content Analysis and primary survey data are employed to identify, code and validate reporting/ethical failures in the articles, i.e., propaganda, logical fallacies, and violations of the Reuters Handbook. Tests are run to measure for 1) shifts in audience attitudes and support for the primary belligerent parties in the Middle East conflict following readings of the sample and, 2) associations between the reporting/ethical failures and audience attitudes/support. Over 1,100 occurrences of reporting/ethical failures across forty-one categories are identified and a significant shift in audience attitudes and support following article readings is observed. Significant associations are found between 1) the use of atrocity propaganda and audience favorability/sympathy toward the Arabs/Palestinians; 2) the use of the appeal to pity fallacy and audience favorability/sympathy toward the Arabs/Palestinians; and 3) the use of atrocity propaganda, appeal to pity and appeal to poverty fallacies, and audience motivation to take supportive action on behalf of the Arabs/Palestinians. It is inferred from the evidence that Reuters engages in systematically biased storytelling in favor of the Arabs/Palestinians and is able to influence audience affective behavior and motivate direct action along the same trajectory. This reflects a fundamental failure to uphold the Reuters corporate governance charter and ethical guiding principles.

\section{AUTHOR INFORMATION}

Henry I. Silverman is an Assistant Professor with the Heller College of Business at Roosevelt University in Chicago and Chair of the Information Systems, Accounting, Finance and Real Estate Department. Dr. Silverman lived in the UK for a number of years where he completed his Doctorate and taught management classes at Royal Holloway, University of London. Employing a combination of Ethnographic Content Analysis (ECA) and traditional quantitative methods, Dr. Silverman's research is focused on the analysis of corporate communications, disclosure materials and financial and legal documents. He pioneered the use of ECA in financial studies and has authored several articles on the topic. E-mail: hsilverman@ roosevelt.edu

\section{REFERENCES}

1. Al-Mughrabi, N. Wed, Jun 9 2010. "Israel eases Gaza embargo to allow snack food in". http://www.reuters.com/article/2010/06/09/us-palestinians-israel-gaza-idUSTRE65820E20100609. Retrieved September 2, 2010.

2. Al-Mughrabi, N. Thu Jul 29, 2010. "Palestinian women dig for new opportunities in Gaza". http://www.reuters.com/article/2010/07/29/us-palestinians-gaza-ditchdiggers-idUSTRE66S2AM20100729. Retrieved September 2, 2010.

3. Altheide, D.L. (1985). "Format and Ideology in TV News Coverage of Iran." Journalism Quarterly, 62: pp. 346-351.

4. $\quad$ Altheide, D.L. (1987). "Ethnographic Content Analysis.” Qualitative Sociology, 10(1) (Spring): pp. 65-77.

5. $\quad$ Altheide, D.L. (1996). Qualitative Media Analysis. Newbury Park, CA: Sage.

6. Anonymous. Reporting by Ece Toksabay and Reuters TV in Istanbul, George Georgiopoulos in Athens. Tue, Jun 1 2010. "Factbox: Comments from activists on Gaza aid convoy". http://www.reuters.com/article/2010/06/01/us-palestinians-israel-turkey-testimonyidUSTRE6501DP20100601. Retrieved September 2, 2010.

7. $\quad$ Anonymous. Thu, Jun 32010. "Q\&A-What happened in the Gaza flotilla seizure, what's ahead?". http://www.reuters.com/article/2010/06/03/us-israel-flotilla-qa-idUSTRE6522NU20100603. Retrieved September 2, 2010.

8. Anonymous. Reporting by Douglas Hamilton and Nidal al-Mughrabi. Thu, Jun 17 2010. "Q\&A: What's changing in Israel's blockade of Gaza?". http://uk.reuters.com/article/2010/06/17/uk-palestinians-israelblockade-gaza-idUKTRE65G28N20100617. Retrieved September 2, 2010. 
9. $\quad$ Anonymous. Thu, Jul 1 2010. "MIDEAST/RISKS (FACTBOX)”. http://www.reuters.com/article/2010/08/06/us-palestinians-cinema-idUSTRE6751Q420100806. Retrieved September 2, 2010.

10. Anonymous. Tue Jul 20, 2010. "Israeli lawmaker visits flashpoint religious site (slide show)". Photo caption. http://www.reuters.com/article/slideshow/idUSTRE66J3UF20100720\#a=1. Retrieved September 2, 2010.

11. Anonymous. Wed Jul 21, 2010 12:56pm EDT. "Israeli shelling kills Gaza militant and wounds 7 (slide show)". http://www.reuters.com/article/slideshow/idUSTRE66K3W120100721\#a=1. Retrieved September 2, 2010.

12. Anonymous. Compiled by Khaled Yacoub Oweis, Yara Bayoumy and David Cutler. Fri Jul 30, 2010. "Q+A - Syria's interests in Lebanon". http://www.reuters.com/article/2010/07/30/us-syria-lebanon-qaidUSTRE66T1JW20100730. Retrieved September 2, 2010.

13. Anonymous. Reporting by Jonathan Lynn and Stephanie Nebehay. July 30 2010. "UN rights body calls for end to Gaza blockade". http://www.reuters.com/article/2010/07/30/us-rights-israelidUSLDE66T0KY20100730. Retrieved September 2, 2010.

14. Anonymous. Sat Jul 31, 2010. "Israeli air strike kills Hamas commander in Gaza (slide show)". http://www.reuters.com/article/slideshow/idUSTRE66U0JX20100731\#a=1. Retrieved September 2, 2010.

15. Anonymous. 04 Aug 2010. "Daughter of Lebanese Sergeant Abdullah Tufayli, who was killed during yesterday's clashes...". Photo caption. http://www.daylife.com/photo/0bYP5ZVgoEejN. Retrieved September 2, 2010.

16. Assadi, M. Fri Aug 6, 2010. "Back to the movies in former West Bank outlaw city". http://www.reuters.com/article/2010/08/06/us-palestinians-cinema-idUSTRE67544720100806. Retrieved September 2, 2010.

17. Banning, J.H. (date unknown). "Ecological Triangulation: An Approach for Qualitative Meta-Synthesis." What Works for Youth with Disabilities Project: U.S. Department of Education.

18. Bassam, L. Mon, Jun 21 2010. "Lebanon says Gaza-bound ship may sail after Israel threat". http://www.reuters.com/article/2010/06/21/us-lebanon-gaza-ship-idUSTRE65K3TN20100621. Retrieved September 2, 2010.

19. Bayoumy, Y. Wed, Jun 23 2010. "UN questions worth of Israeli vow to ease Gaza grip". http://www.reuters.com/article/2010/06/23/idUSLDE65M19R. Retrieved September 2, 2010.

20. Brock, P. (1993-94). "Dateline Yugoslavia: The Partisan Press". Foreign Affairs, 93, 152-172.

21. Brown, J.A.C. (1963). Techniques of Persuasion: From Propaganda to Brainwashing. Baltimore, MD: Penguin.

22. Bryant, D.C. (1953). "Rhetoric: It's Function and Scope". Quarterly Journal of Speech, 39, 401-424.

23. Bull, A. Tue, Jun 29 2010. "Obama, Saudi King discuss 2-state Mideast solution". http://www.reuters.com/article/2010/06/30/us-usa-saudi-mideast-idUSTRE65S68N20100630. Retrieved September 2, 2010.

24. Chambers, E. (2000). “Applied Ethnography” in N. Denzin \& Y. Lincoln (eds.), Handbook of Qualitative Research, ( $2^{\text {nd }}$ ed.). Thousand Oaks, CA: Sage.

25. Chikhi, L. Wed, Jun 2 2010. "Israelis "humiliated" ship activists: eyewitness". http://www.reuters.com/article/2010/06/02/us-israel-flotilla-algerian-idUSTRE6513EA20100602. Retrieved September 2, 2010.

26. Chomsky, N. (1992). “A View from Below". In M.J. Hogan (Ed.), The End of the Cold War: It's Meaning and Implications. Cambridge, UK: Cambridge University Press.

27. Denzin, N.K. (1978). The Research Act: A Theoretical Introduction to Sociological Methods. New York: McGraw-Hill.

28. Ellul, J. (1965). Propaganda: The Formation of Men's Attitudes. New York: Knopf.

29. Evans, R. Wed, Jun 2 2010. "U.N. rights body sets probe into flotilla raid". http://www.reuters.com/article/2010/06/02/us-israel-flotilla-rights-idUSTRE65151420100602. Retrieved September 2, 2010.

30. Fisher-Ilan, A. Mon, Jun 21 2010. "Israeli panel revives East Jerusalem housing plan". http://www.reuters.com/article/2010/06/21/us-palestinians-israel-idUSTRE65K5FK20100621. Retrieved September 2, 2010. 
31. Fisher-Ilan, A. Sun Jul 11, 2010. "Senior Palestinian calls Jerusalem a "time bomb". http://www.reuters.com/article/2010/07/11/us-palestinians-israel-jerusalem-idUSTRE66A21H20100711. Retrieved September 2, 2010.

32. Fisher-Ilan, A. Tue Jul 13, 2010. "Arab MP under pressure in Israel over Gaza aid ship". http://www.reuters.com/article/2010/07/13/us-israel-flotilla-lawmaker-idUSTRE66C68I20100713. Retrieved September 2, 2010.

33. Gamst, F. (1980). The Hoghead: An Industrial Ethnology of the Locomotive Engineer, New York: Holt Rinehart and Winston.

34. Glaser, B.G. and Strauss, A.L. (1967). The Discovery of Grounded Theory: Strategies for Qualitative Research. New York: Aldine.

35. Guba, E. G. (1978). Toward a Methodology of Naturalistic Inquiry in Educational Evaluation. Monograph 8. Los Angeles: UCLA Center for the Study of Evaluation.

36. Gula, R.J. (2007). Red Herrings, Straw Men and Sacred Cows: How We Abuse Logic in Our Everyday Language. Mount Jackson, VA: Axios Press.

37. Hamilton, D. Thu Aug 12, 2010. "Major powers drawing up framework for Mideast talks". http://af.reuters.com/article/worldNews/idAFTRE67B1PV20100812. Retrieved September 2, 2010.

38. Hammersley, M. and Atkinson, P. (1983). Ethnography: Principles in Practice, Tavistock Publications.

39. Hammond, P. and Herman, E. (2000). Degraded Capability: The Media and the Kosovo Crisis. London: Pluto Press.

40. Heller, J. Tue Jul 13, 2010. "Israel razes inhabited Palestinian home in Jerusalem". http://www.reuters.com/article/2010/07/13/us-palestinians-israel-jerusalem-idUSTRE66C1OW20100713. Retrieved September 2, 2010.

41. Heller, J. Wed Aug 25, 2010. "Prospects bleak for peace deal - Israel's Lieberman". http://www.reuters.com/article/2010/08/26/us-palestinians-israel-idUSTRE67O5GK20100826. Retrieved September 2, 2010.

42. Heller, J. Sun Aug 29, 2010. “Abbas, Palestinians should die: Israeli rabbi”. http://www.reuters.com/article/2010/08/29/us-palestinians-israel-rabbi-idUSTRE67S0GU20100829. Retrieved September 2, 2010.

43. Hitler, A. (2009). Mein Kampf. Ed. Michael Ford. Camarillo, CA: Elite Minds. (Original work published 1925, 1926).

44. Hodder, I. (2000). "The Interpretation of Documents and Material Culture" in N. Denzin \& Y. Lincoln (eds.), Handbook of Qualitative Research, ( $2^{\text {nd }}$ ed.). Thousand Oaks, CA: Sage.

45. Hudson, A. Thu, Jun 3 2010. "Flotilla activists given hero's welcome in Turkey". http://in.reuters.com/article/2010/06/03/israel-flotilla-turkey-return-idINLDE65200M20100603. Retrieved September 2, 2010.

46. Jowett G.S. and O’Donell, V. (1999). Propaganda and Persuasion. Thousand Oaks, CA: Sage.

47. Kelland, K. Fri, Jul 2 2010. "Gaza siege damages Palestinians' health: study". http://uk.reuters.com/article/2010/07/02/health-us-gaza-health-idUKTRE6614F620100702. Retrieved September 2, 2010.

48. Kit, Z. Fri, Jun 11 2010. "Jordan's Queen Noor goes Hollywood -- for a cause". http://www.reuters.com/article/2010/06/12/us-queennoor-idUSTRE65B05B20100612. Retrieved September 2, 2010.

49. Krippendorff, K. (2004). Content Analysis: An Introduction to Its Methodology. Thousand Oaks, CA: Sage.

50. Lamay, C. (1991). "By the Numbers I: The Bibliometrics of War". In The Media at War The Press and the Persian Gulf Conflict (pp. 41-44). New York: Freedom Forum.

51. Lasswell, H. and Blumenstock, D. (1939). World Revolutionary Propaganda: A Chicago Study. New York: Knopf.

52. Laswell, H. (1927). Propaganda Technique in the World War. New York: Knopf.

53. Lee, A.M. and Lee, E.B. (1972). The Fine Art of Propaganda. San Francisco, CA: International Society for General Semantics.

54. Lewis, O. Fri, Jun 4 2010. "Israel prepares to intercept Gaza-bound ship". http://www.reuters.com/article/2010/06/04/us-israel-flotilla-idUSTRE65005R20100604. Retrieved September 2, 2010. 
55. Likert, R. (1932). "A Technique for the Measurement of Attitudes". Archives of Psychology, 140.

56. Linebarger, P.M.A. (1954). Psychological Warfare. New York: Duell, Sloan, and Pearce.

57. Lyon, A. Mon, Aug 2 2010. "ANALYSIS-Calm on Israel-Lebanon front belied by talk of war". http://www.reuters.com/article/2010/08/02/us-mideast-war-idUSTRE6713CR20100802. Retrieved September 2, 2010.

58. Lyon, A. Thu Aug 19, 2010. "ANALYSIS-Lebanese doubt Hariri tribunal will deliver justice". http://www.reuters.com/article/2010/08/19/idUSLDE67H17M. Retrieved September 2, 2010.

59. Macdonald, A. Mon Jun 21, 2010. "Witness - Writing on the walls in the Holy Land". http://www.reuters.com/article/2010/06/21/us-witness-palestinians-israel-idUSTRE65K2PZ20100621. Retrieved September 2, 2010.

60. Macdonald, A. Mon, Jun 28 2010. "In Quarter of Jerusalem, Armenians fear for future". http://www.reuters.com/article/2010/06/28/idUSMAC449255. Retrieved September 2, 2010.

61. McCombs, M.E. and Shaw, D.L. (1972). "The Agenda-Setting Function of Mass Media". Public Opinion Quarterly, Vol. 36 pp. 176-187

62. Merton, R. (1968). Social Theory and Social Structure. New York: Free Press.

63. Nasr, J. 25 Jun 2010. "Israeli air strikes kill two in Gaza - Palestinians". http://af.reuters.com/article/egyptNews/idAFLDE65O14R20100625. Retrieved September 2, 2010.

64. Nebehay, S. Mon, Jun 14 2010. "Israel's Gaza blockade breaks law, says ICRC". http://af.reuters.com/article/worldNews/idAFTRE65D01120100614. Retrieved September 2, 2010.

65. Nebehay, S. Tue, Jun 29 2010. "Israel plan to raze homes illegal, U.N. rights envoy says". http://in.reuters.com/article/2010/06/29/idINIndia-49747120100629. Retrieved September 2, 2010.

66. Oweis, K.Y. Mon Aug 16, 2010. "Hamas and secular groups, oppose direct talks with Israel". http://www.reuters.com/article/2010/08/16/us-palestinians-israel-talks-idUSLDE67E0CD20100816. Retrieved September 2, 2010.

67. Paratkanis, A and Aronson, E. (1991). Age of Propaganda: The Everyday Use and Abuse of Persuasion. New York: Freeman.

68. Patton, M.Q. (1990). Qualitative Evaluation and Research Methods. Thousand Oaks, London, New Delhi: Sage.

69. Patton, M.Q. (1999). "Enhancing the Quality and Credibility of Qualitative Analysis." Health Services Research, (Dec).

70. Perry, T. Sat Jul 10, 2010. "Abbas says wants progress for direct Mideast talks". http://www.reuters.com/article/2010/07/10/us-palestinians-israel-abbas-idUSTRE6691G320100710. Retrieved September 2, 2010.

71. Perry, T. Sat, Jul 17 2010. "Abbas sets terms for Mideast talks". http://www.reuters.com/article/2010/07/17/us-palestinians-israel-idUSTRE66G0IQ20100717. Retrieved September 2, 2010.

72. Perry, T. Tue Jul 27, 2010. "FEATURE-Gazans want "Marshall Plan", Israel policy falls short". http://in.reuters.com/article/2010/07/27/idINIndia-50420920100727. Retrieved September 2, 2010.

73. Perry, T. Sat Aug 21, 2010. "Dejected Palestinians see no hope in peace talks". http://www.reuters.com/article/2010/08/21/us-palestinians-israel-dejection-idUSTRE67K1ER20100821. Retrieved September 2, 2010.

74. Perry, T. Mon Aug 30, 2010. "Palestinian PM Fayyad says time for Israeli answers". http://www.reuters.com/article/2010/08/30/us-palestinians-israel-idUSTRE67T38U20100830. Retrieved September 2, 2010.

75. Perry, T. Mon, Aug 30 2010. "ANALYSIS-To Palestinians, third intifada as unlikely as peace". http://www.reuters.com/article/2010/08/30/us-palestinians-israel-stability-idUSTRE67S1DA20100830. Retrieved September 2, 2010.

76. Perry, T. and Macdonald, A. Fri, Jun 4 2010. “ANALYSIS-Israel to give tactical ground to Gaza pressure". http://www.reuters.com/article/2010/06/04/us-israel-flotilla-pressureidUSTRE65325D20100604. Retrieved September 2, 2010.

77. Plummer, K. (1983). Documents of Life: An Introduction to the Problems and Literature of a Humanistic Method. London: George Allen \& Unwin. 
78. Pomeroy, R. Sun, Jun 6 2010. "Iran Revolutionary Guards ready to escort Gaza ships". http://www.reuters.com/article/2010/06/06/us-israel-flotilla-iran-idUSTRE6550WZ20100606. Retrieved September 2, 2010.

79. Pomeroy, R. 14 Jun 2010. "Iranian aid ships head for Gaza". http://af.reuters.com/article/energyOilNews/idAFLDE65D0HG20100614?sp=true. Retrieved September 2, 2010.

80. Pratkanis, A.R. and Turner, M.E. (1996). "Persuasion and Democracy: Strategies for Increasing Deliberative Participation and Enacting Social Change”. Journal of Social Issues, 52, 187-205.

81. Qualter, T.H. (1962). Propaganda and Psychological Warfare. New York: Random House.

82. Read, J. (1941). Atrocity Propaganda, 1914-1919. New Haven, CT: Yale University Press.

83. Rogers, E.M. (1994). A History of Communication Study. New York: Free Press.

84. Rogers, E.M. (1994). A History of Communication Study. New York: Free Press.

85. Rosenthal, S.P. (1934). "Changes of Socioeconomic Attitudes Under Radical Motion Picture Propaganda". Archives of Psychology, 166.

86. Sawafta, A. and Hamilton, D. Wed Jul 7, 2010. "Palestinians wary of direct peace talks with Israel". http://www.reuters.com/article/2010/07/07/us-palestinians-israel-idUSTRE6662NH20100707. Retrieved September 2, 2010.

87. Scott, W.A. (1955). "Reliability of Content Analysis: The Case of Nominal Scale Coding." Public Opinion Quarterly, 19: 321-325.

88. Shaw, D.L. and McCombs, M.E. (1974). The Emergence of American Political Issues: The Agenda-Setting Function of the Press. St Paul, MN: West.

89. Silverman, D. (1993). Interpreting Qualitative Data: Methods for Analysing Talk, Text and Interaction. London: Sage.

90. Silverman, H.I. (2008). “Mutual Fund Risk-Return Profiles” A Novel Use of Triangulation”. Journal of Risk Management in Financial Institutions, Vol. 1, 2, pp. 191-222.

91. Smith, T. J. (1989). Propaganda: A Pluralistic Perspective. Westport, CT: Praeger.

92. Smith, T., Sells, S. and Clevenger. (1994). "Ethnographic Content Analysis of Couple and Therapist Perceptions in a Reflective Team Setting", Journal of Marital and Family Therapy, 20(3): pp. 267-286.

93. Sproule, J.M. (1994). Channels of Propaganda. Bloomington, IN. Edinfo.

94. Triandis, H.C. (1977). Interpersonal Behavior. Monterey, CA: Brooks/Cole.

95. United States General Accounting Office. "Content Analysis: A Methodology for Structuring and Analyzing Written Materials." USGAO Publication No. 10.1.1. Gaithersburg, Maryland: U.S. Government Printing Office.

96. Villelabeitia, I. Mon, May 31 2010. "Factbox: Turkish charity group behind Gaza-bound convoy". http://www.reuters.com/article/2010/06/01/us-palestinians-israel-turkey-group-factidUSTRE64U4SO20100601. Retrieved September 2, 2010.

97. Webb, E.J., Campbell, D.T., Schwartz, R.D. and Sechrest, L. (1996). Unobtrusive Measures. Chicago: Rand McNally.

98. Weschler, L. (1983, April 11). “A State of War-1". New Yorker, pp. 45-102.

99. Williams, D. Wed, Jun 30 2010. "Israel holds Hamas man facing exile from Jerusalem". http://in.reuters.com/article/2010/06/30/idINIndia-49786920100630. Retrieved September 2, 2010.

100. Zimbardo, P.G. and Leippe, M.R. (1991). The Psychology of Attitude Change and Social Influence. New York: McGraw-Hill. 


\section{NOTES}

